\title{
Erratum: Biological survey of a cloud forest in southwestern Mexico: plants, amphibians, reptiles, birds, and mammals
}

In the article "Biological survey of a cloud forest in southwestern Mexico: plants, amphibians, reptiles, birds, and mammals" with DOI code number http://dx.doi.org/10.1590/1676-0611-bn-2017-0444 published at Biota Neotropica 18(2): e20170444,

\begin{tabular}{|ll|}
\hline \multicolumn{1}{|c|}{ Where you read: } & \multicolumn{1}{c|}{ Should be read: } \\
\hline $\begin{array}{l}\text { (...) and four threatened species (e.g., Boa imperator, Thamnophis } \\
\text { godmani, and Trimorphodon quadruplex; Figure 2, Appendix 2). }\end{array}$ & $\begin{array}{l}\text { (...) and four threatened species (e.g., Boa sigma, Thamnophis } \\
\text { godmani, and Trimorphodon biscutatus; Figure 2, Appendix 2). }\end{array}$ \\
\hline $\begin{array}{l}\text { In particular, Carpinus caroliniana, Eupherusa poliocerca, } \\
\text { Herpailurus yagouaroundi, and Trimorphodon quadruplex are } \\
\text { threatened (...). }\end{array}$ & $\begin{array}{l}\text { In particular, Carpinus caroliniana, Eupherusa poliocerca, } \\
\text { Herpailurus yagouaroundi, and Trimorphodon biscutatus } \text { are } \\
\text { threatened (...). }\end{array}$ \\
\hline
\end{tabular}

And in the "Appendix 2 - List of amphibian and reptile species recorded in a cloud forest of southern Mexico",

\begin{tabular}{|ll|}
\hline \multicolumn{1}{|c|}{ Where you read: } & Should be read: \\
\hline Dryophytes eximius & Dryophytes arboricola \\
Plectrohyla bistincta & Sarcohyla bistincta \\
Plectrohyla pentheter & Sarcohyla pentheter \\
Marisora unimarginata & Marisora brachypoda \\
Boa imperator & Boa sigma \\
Trimorphodon quadruplex & Trimorphodon biscutatus \\
Geophis sieboldi & Geophis occabus \\
\hline
\end{tabular}

